\title{
Sedimentary geochemical record of human-induced environmental changes in Huanggaihu Lake in the middle reach of the Yangtze River, China
}

\author{
Shuchun YAO, ${ }^{*}$ Bin XUE \\ State Key Lab of Lake Science and Environment, Nanjing Institute of Geography and Limnology, Chinese Academy of Sciences, \\ Nanjing, 210008, China \\ *Corresponding author: shchyao@niglas.ac.cn
}

\begin{abstract}
Total organic carbon (TOC), total nitrogen (TN), total phosphorus (TP) and heavy metals were determined along with stable isotope ratios of carbon and nitrogen $\left(\delta^{13} C_{\text {org }}\right.$ and $\left.\delta^{15} N\right)$ in an $86 \mathrm{~cm}$ sediment core from Huanggaihu Lake, located in the middle reach of the Yangtze River, China. These geochemical and isotopic records provide a continuous history of lake productivity and the trophic state of Huanggaihu Lake over the past 150 years. Before the 1960s, organic matter, nutrients and heavy metal contents were low, revealing the low trophic state and pollution inputs at Huanggaihu Lake. High sediment mass accumulation rates and low clay content suggested increased catchment erosion related to human activities such as railway construction and forest clearing during the 1910s-1940s in the catchment area. Since the $1960 \mathrm{~s}, T O C, T N$ and $\delta^{15} N$ have increased along with decreased $\delta^{13} C_{\text {org }}$, indicating an increase in the primary productivity of Huanggaihu Lake. After the year 2000, the TOC, TN and TP decreased or remained stable, and the $\delta^{13} C_{\text {org }}$ and $\delta^{15} N$ dropped slightly, indicating minor improvement in the lake's water quality.
\end{abstract}

Key words: Sediment, stable isotope, lake productivity, Lake Huanggaihu.

Received: February 2014. Accepted: June 2014.

\section{INTRODUCTION}

The middle and lower reaches of the Yangtze River basin are rich in shallow water lakes, many of which are important freshwater sources of drinking water (Wang and Dou, 1998; Cao, 2000). With the increase of population and the development of the economy in recent decades, increasingly pollutants (point and non-point sources) such as nutrients and heavy metals have been discharged into these lakes, which are known to have numerous effects on aquatic ecosystems (Qin et al., 2007). The current annual average total phosphorus (TP) concentration ranges between 30 and $548 \mathrm{mg} \mathrm{L}^{-1}$, according to a recent study in the region (Yang et al., 2008). The lakes receive high nutrient inputs and are therefore relatively productive [ $86 \%$ of the lakes are eutrophic (Yang et al., 2010)]. Lake eutrophication has been a concern of local governments and scientists. Long-term lake water data are necessary to understand the process of lake eutrophication and the human impact on lake systems. However, the monitoring data on the lakes across the middle and lower reaches of the Yangtze River, unlike the historical records in China, only extend to the past two decades, and do not record the beginning of the water deterioration.

Lake sediments have proved to be useful in tracking past lake environmental changes because each layer of buried sediments represents a record of environmental conditions at different times in the past. Environmental changes leave geochemical signals in the sediment records of lakes that can be used to infer past lake environments (Last and Smol, 2001; Meyers, 2003). Total organic carbon (TOC), total nitrogen (TN), total phosphorus (TP) and their composition and ratios in lake sediments have been used to assess the trophic state and organic matter sources in numerous lakes (Brenner et al., 2001, 2006; Liu et al., 2010). The drawback of these proxies is that they are easily affected by post-depositional processes (Hodell and Schelske, 1998; Ginn et al., 2012). Stable isotopic carbon and nitrogen $\left(\delta^{13} \mathrm{C}_{\text {org }}\right.$ and $\left.\delta^{15} \mathrm{~N}\right)$ in sediment organic matter $(\mathrm{OM})$ have proved to be effective geochemical proxies of historic changes in a lacustrine trophic state in many studies (Schelske and Hodell, 1991, 1995; Routh et al., 2004), although bacterial degradation during early diagenesis in the anoxic sediments may change the isotopic signal (Lehmann et al., 2002).

Sound management of impacted lake basins requires a thorough understanding of both the natural (baseline) sedimentation regime and changes caused by human activities, i.e. pollution history of a lake system. In this study, evidence for the recent eutrophication of Huanggaihu Lake is outlined from an analysis of TOC, TN, TP, $\delta^{13} \mathrm{C}_{\text {org }}$ and $\delta^{15} \mathrm{~N}$ of a short $(86 \mathrm{~cm})$ sediment core from the Yangtze River lake. We also used sediment trace element concentrations and stable lead isotopes to reconstruct the history of environmental contamination at Huanggaihu Lake. The isotopic compositions of lead ores vary depend- 
ing on the source of lead, which allows the lead isotopic composition to be used to infer lead pollution and sources (Marcantonio et al., 2002; Yang et al., 2007; Cheng and $\mathrm{Hu}, 2010)$. This study demonstrates the utility of geochemical variables to discern natural sediments from those subject to human impacts and explore the historical trophic changes and environmental disturbances in the Huanggaihu Lake system.

\section{METHODS}

\section{Study site}

Huanggaihu Lake is a shallow, freshwater body (Tab. 1). The TP concentration was high $\left(100 \mu \mathrm{g} \mathrm{L}^{-1}\right)$ in 2001-2002. An investigation conducted by the Nanjing Institute of Geography and Limnology, Chinese Academy of Sciences in 2007-2008 indicated that Huanggaihu is now mesoeutrophic (Tab. 1) (Yang et al., 2010). Located in the middle reach of the Yangtze River Basin, the lake is governed under the Hunan Province and Hubei Province (Fig. 1). The Pan River and Yanshan River feed into the lake from the southeast and east, respectively. A long river connects the lake to the Yangtze River (Fig. 1). In 1958, a water-control gate was established at Tishanzui (Chorography Compiling Committee of Puqi County, 1995). Since then, Huanggaihu Lake has become a reservoir-type lake under artificial control.

Tab. 1. Characteristics of Huanggaihu Lake.

\begin{tabular}{lc}
\hline Lake area $\left(\mathrm{km}^{2}\right)$ & 86 \\
\hline Average water depth $(\mathrm{m})$ & 4.2 \\
\hline Max water depth $(\mathrm{m})$ & 4.5 \\
\hline Lake volume $\left(\mathrm{m}^{3}\right)$ & $3.9 \times 10^{8}$ \\
\hline Catchment area $\left(\mathrm{km}^{2}\right)$ & 1677 \\
\hline Chlorophyll a $\left(\mu \mathrm{g} \mathrm{L}^{-1}\right)$ & $44.81(16.68-74.88)$ \\
\hline Total nitrogen $\left(\mathrm{mg} \mathrm{L}^{-1}\right)$ & 0.56 (spring), 3.51 (autumn) \\
\hline Total phosphorus $\left(\mathrm{mg} \mathrm{L}^{-1}\right)$ & 0.024 (spring), 0.110 (autumn) \\
\hline Secchi disk depth $(\mathrm{cm})$ & $25-85$ \\
\hline Total population in catchment & 130,800 \\
\hline
\end{tabular}

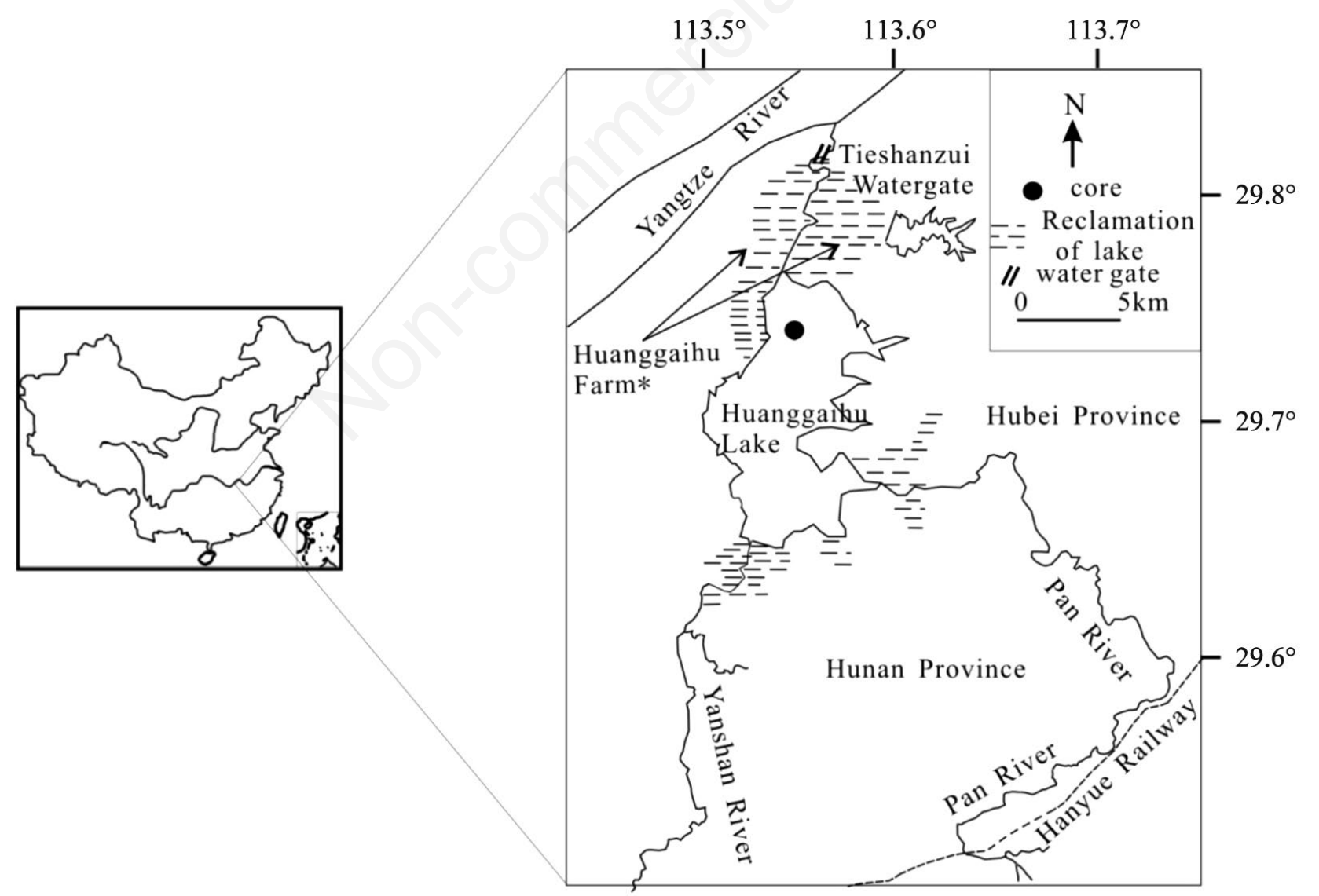

Fig. 1. Location map of the study area showing Huanggaihu Lake and the coring site. The farm on the left is in Hunan Province, and the one on the right is in Hubei Province. 
Two Huanggaihu farms, one in Hubei Province and the other in Hunan province, were established during 1959-1960 (Chorography Compiling Committee of Puqi County, 1995), after which large-scale reclamation of the lake began. The surface area of Huanggaihu Lake was approximately $162 \mathrm{~km}^{2}$ in the early $1950 \mathrm{~s}$. After reclamation, approximately $76 \mathrm{~km}^{2}$ of the lake's water area was lost. The newly formed land is mainly distributed in the two farms. Huanggaihu Farm in Hubei Province had a population of 497 inhabitants in 1959 (Chorography Compiling Committee of Puqi County, 1995), after which people immigrated to the region continuously. The population of Huanggaihu Farm in Hubei Province was 5480 inhabitants in 1985 and 12,067 in 2006. A rapid population increase also occurred in Huanggaihu Farm in Hunan Province; as reported, the population reached 19,580 in 2006 in Huanggaihu Farm in Hunan Province.

\section{Sampling and laboratory analysis}

Short sedimentary cores were obtained from the northern part of Huanggaihu Lake using a gravity corer with a Plexiglas core tube $150 \mathrm{~cm}$ in length and with a $59-\mathrm{mm}$ inner diameter in May 2011. After being collected, the cores were kept in a vertical position and carefully sectioned in the field. Immediate subsampling can prevent disturbance of the surface sediments during transportation of the whole core sediments. In this study, all sediments were cut in intervals of $1 \mathrm{~cm}$. The subsamples were kept in tightly sealed plastic containers and stored at a temperature of $4^{\circ} \mathrm{C}$ prior to analyses. The core presented here contains the most intact and least disturbed record (HGH2011-02).

Sedimentation rates were determined from depth profiles of ${ }^{210} \mathrm{~Pb}$ and ${ }^{137} \mathrm{Cs}$, which were measured using an EG \& G Ortec Gamma Spectrometer. ${ }^{137} \mathrm{Cs}$ was measured at $662 \mathrm{keV}$, while ${ }^{210} \mathrm{~Pb}$ was determined via gamma emission at $46.5 \mathrm{keV}$ and ${ }^{226} \mathrm{Ra}$ at 295 and $352 \mathrm{keV}$-rays emitted by its daughter isotope, ${ }^{214} \mathrm{~Pb}$. The counting times of each individual sample ranged between $4 \times 10^{4}$ and $9 \times 10^{4} \mathrm{~s}$. The counter error increased with decreased activity of ${ }^{210} \mathrm{~Pb}$. For sediments with ${ }^{210} \mathrm{~Pb}$ activity higher than $500 \mathrm{~Bq} \mathrm{~kg}^{-1}$, the counter error was below $5 \% .{ }^{137} \mathrm{Cs}$ was used to identify the 1963 nuclear weapons peak, which was then used as part of a constant rate of supply (CRS) model to calculate $\mathrm{a}^{210} \mathrm{~Pb}$ chronology for the core (Appleby, 2001). The CRS model was chosen due to the complexity and heavily impacted nature of the Huanggaihu Lake system.

The dried and ground samples (approximately 0.125 $\mathrm{g}$ each) were digested with $\mathrm{HCl}-\mathrm{HNO}_{3}-\mathrm{HClO}_{4}$ in a Teflon beaker. Elements $(\mathrm{Pb}, \mathrm{Ag}, \mathrm{Cd})$ were measured using inductively coupled plasma mass spectroscopy (ICP-MS) (7700x; Agilent Technologies, Santa Clara, CA, USA). $\mathrm{TP}$ and $\mathrm{Ca}$ were measured using inductively coupled plasma atomic emission spectrometry (ICP-AES, Profile
DV). Data quality was ensured through the use of duplicates, blanks, and standard reference materials, such as GSD-11, which was supplied by the Chinese Academy of Geological Sciences. Replicates were measured every 10 sediment samples. The recoveries of elements varied, but all fell within the range of $92-106 \%$, and the relative standard deviation (RSD) was better than 5\%. The isotopes ${ }^{206} \mathrm{~Pb},{ }^{207} \mathrm{~Pb}$ and ${ }^{208} \mathrm{~Pb}$ were measured using ICP-MS. An international standard reference material (SRM981-NIST) was selected for calibration. The average measured ratio of ${ }^{206} \mathrm{~Pb} /{ }^{207} \mathrm{~Pb}$ of the external standard (GBW04426) was $1.1516 \pm 0.0009$ (for ten replicates). Good agreement was obtained between the measured lead isotope ratios and the certified values for GBW04426 (1.1525).

For the carbon isotope ratios of sedimentary organic matter $\left(\delta^{13} \mathrm{C}_{\text {org }}\right)$, the samples were treated with $\mathrm{HCl}(5 \%)$ to remove carbonate (Brodie et al., 2011). Afterward, the samples were centrifuged, rinsed repeatedly with deionized water until neutral $\mathrm{pH}$ was achieved, and freeze dried. An untreated sample was used for analyses of the nitrogen isotope composition of the sediments $\left(\delta^{15} \mathrm{~N}\right)$. The isotope ratios were determined using a Finnigan MAT Delta Plus mass spectrometer coupled with a Flash EA 1112 elemental analyzer. The results are expressed as the per mil deviation relative to conventional standards (PDB for carbon, AIR for nitrogen). Analytical precision for standards was within $\pm 0.05 \%$ for $\delta^{13} \mathrm{C}$ and $\pm 0.15 \%$ for $\delta^{15} \mathrm{~N}$.

For grain size analysis, approximately $0.5 \mathrm{~g}$ of dried samples was pretreated for measurement on a Malvern Laser Grain Size instrument. Prior to analysis, diluted $\mathrm{HCl}$ and $10 \% \mathrm{H}_{2} \mathrm{O}_{2}$ were used to remove carbonate and organic matter, respectively. The TOC and TN contents were measured using a CE440 elemental analyzer (Teledyne Leeman Labs, Hudson, NH, USA).

\section{RESULTS}

\section{Chronology and mass sedimentation rate}

${ }^{137} \mathrm{Cs}$ was first detected in the $\mathrm{HGH} 2011-02$ core at a depth of 20 to $21 \mathrm{~cm}$, approximately representing its initial appearance in the environment because of atmospheric nuclear weapon tests conducted in the early 1950s. A prominent ${ }^{137} \mathrm{Cs}$ peak at $14-15 \mathrm{~cm}$ could have formed in 1963, when the ${ }^{137} \mathrm{Cs}$ depositional flux from the atmosphere reached a maximum, and could thus serve as a reliable geochronological marker in depositional environments worldwide (Baskaran and Naidu, 1995).

$\mathrm{The}^{210} \mathrm{~Pb}_{\text {ex }}\left(\right.$ excess ${ }^{210} \mathrm{~Pb}$ ) activities decreased exponentially with the increase of depth in the core (Fig. 2). The mass sedimentation rate calculated from the depth interval of $0 \mathrm{~cm}$ to $56 \mathrm{~cm}$ was approximately $0.27 \mathrm{~g} \mathrm{~cm}^{-2} \mathrm{a}^{-1}$ $\left(\mathrm{r}^{2}=0.86\right)$ using the CIC (constant initial concentration) model. If this sedimentation rate were constant over the entire length of the core, the age of the $20.5 \mathrm{~cm}$ layer (cumu- 
lative mass depth of $10.8 \mathrm{~g} \mathrm{~cm}^{-2}$ ) would be approximately the year 1970, and the age of the $14.5 \mathrm{~cm}$ layer of the core (cumulative mass depth of $5.8 \mathrm{~g} \mathrm{~cm}^{-2}$ ) would be approximately the year 1989 .

The results of the ${ }^{137} \mathrm{Cs}$ profile revealed that the CIC model of ${ }^{210} \mathrm{~Pb}$ is not suitable to establish the time sequence for the HGH2011-02 core. When compared with the $1963{ }^{137} \mathrm{Cs}$ peak, the ${ }^{210} \mathrm{~Pb}$ CRS age $(14-15 \mathrm{~cm}$, dated to the mid-1980s) (Fig. 2) was found to be too young, reflecting a decrease in sedimentation rates. The ${ }^{137} \mathrm{Cs}$ data were therefore used to constrain the ${ }^{210} \mathrm{~Pb}$ data and to produce a composite age model (Appleby, 2001). The calculated sediment accumulation rates (SARs) varied markedly over the last 150 years (Fig. 2). From the 1900s to the mid- $20^{\text {th }}$ century, the SARs rose rapidly and peaked in the late 1930s, after which point they declined through to the top of the core.

Since the ${ }^{210} \mathrm{~Pb}_{\text {ex }}$ was only detectable up to a depth of $56 \mathrm{~cm}$ (Fig. 2), the calculation of total mass accumulation rates was restricted to the upper $56 \mathrm{~cm}$ of the core. Therefore, only the change in the lake environment and the nutrient input into the lake since approximately 1860 will be discussed in this study.

\section{Total organic carbon, total nitrogen and total phosphorus}

Between the bottom and a depth of $18.5 \mathrm{~cm}$, the TOC concentrations were between $0.5 \%$ and $0.9 \%$ by dry weight, showing a small increase before $39.5 \mathrm{~cm}$ and relatively low value between 39.5 and $18.5 \mathrm{~cm}$ (Fig. 3). The TOC started to increase rapidly above $14.5 \mathrm{~cm}$ (corresponding to the early $1960 \mathrm{~s}$ ), peaking at nearly $2.5 \%$ at the uppermost sediments in the HGH2011-02 core (Fig. 3). The TN concentration varied at approximately $0.1 \%$ before it increased rapidly above $14.5 \mathrm{~cm}$ (Fig. 3). The TOC/TN atomic ratios varied between 5.8 and 9.9, showing a slightly increasing trend before peaking at approximately $21-27 \mathrm{~cm}$. The TP concentration was stable and low, with an average of $744 \mathrm{mg} \mathrm{kg}^{-1}$ before a depth of $14.5 \mathrm{~cm}$. A rapid increase of TP occurred in the upper $14.5 \mathrm{~cm}$ sediments.

\section{Carbon and nitrogen isotopic composition}

The $\delta^{13} \mathrm{C}_{\text {org }}$ values ranged from $-26.0 \%$ to $-24.1 \%$, with the more negative values appearing in the surface sediments (Fig. 3). The $\delta^{15} \mathrm{~N}$ values ranged from $2.5 \%$ to $7.0 \%$, showing a quite different pattern when compared with $\delta^{13} \mathrm{C}_{\text {org }}$ (Fig. 3). In the upper $14.5 \mathrm{~cm}$ sediments, the $\delta^{15} \mathrm{~N}$ increased while $\delta^{13} \mathrm{C}_{\text {org }}$ showed a decreasing trend.

\section{Trace elements and lead isotope ratio}

Cadmium, lead and silver started to increase upward at the $14-15 \mathrm{~cm}$ layer around the 1960s (Fig. 3). In recent years, however, the accumulation of these trace elements either decreased or remained the same. Similar to the three trace elements, ${ }^{206 / 207} \mathrm{~Pb}$ remained stable before it declined upward from $18 \mathrm{~cm}$, finally increasing from $7 \mathrm{~cm}$ to the top sediment.

\section{DISCUSSION}

Mass accumulation rates can compensate for the effects of dilution. However, sediment accumulation rate data are considerably less precise than the concentration
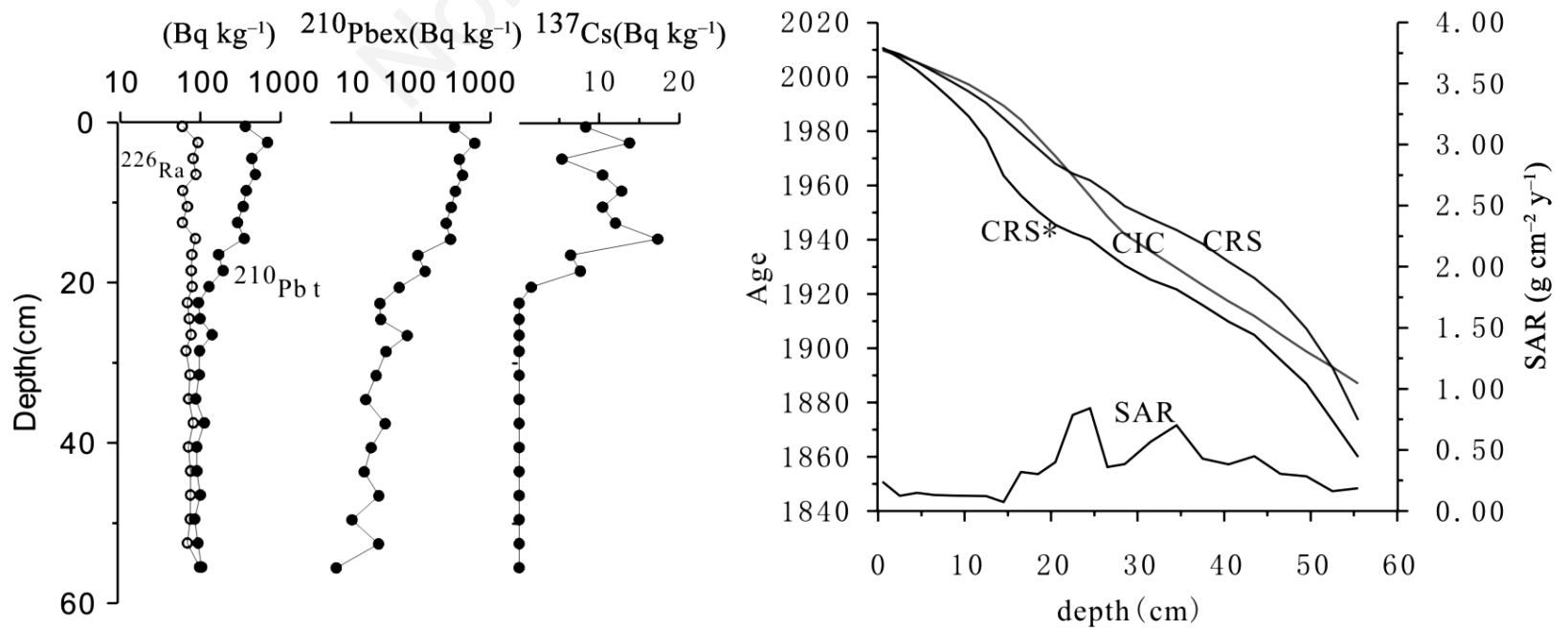

Fig. 2. Vertical profiles of ${ }^{226} \mathrm{Ra},{ }^{210} \mathrm{Pbt}\left(\right.$ total $\left.{ }^{210} \mathrm{~Pb}\right),{ }^{210} \mathrm{~Pb}$ ex and ${ }^{137} \mathrm{Cs}$ (left), chronology and sedimentation rate (right) of Huanggaihu Lake. CRS*, composite model derived from the constant rate of supply (CRS) model; CIC, constant initial concentration; SAR, sediment accumulation rates. 
data especially for shallow lakes, and presenting results as accumulation rates reduces precision. Therefore we did not convert the nutrient and heavy metal concentrations to accumulation rates in this study.

\section{Change of sediment accumulation rate}

The higher SARs during the period 1900-1950 reflected the beginning of an increase in the intensity of human activity associated with soil disturbance in the catchment area. During this period, terrestrial material was washed into the lake from surface runoff, as evidenced by the high content of coarse materials and the high TOC/TN value in the period (Fig. 3). Investigation showed that calcareous soil is mainly distributed around the Yuehan railway (Fig. 1). The terrestrial material-enriched $\mathrm{Ca}$ from the calcareous region was transported into Huanggaihu Lake mainly through the Pan River, which

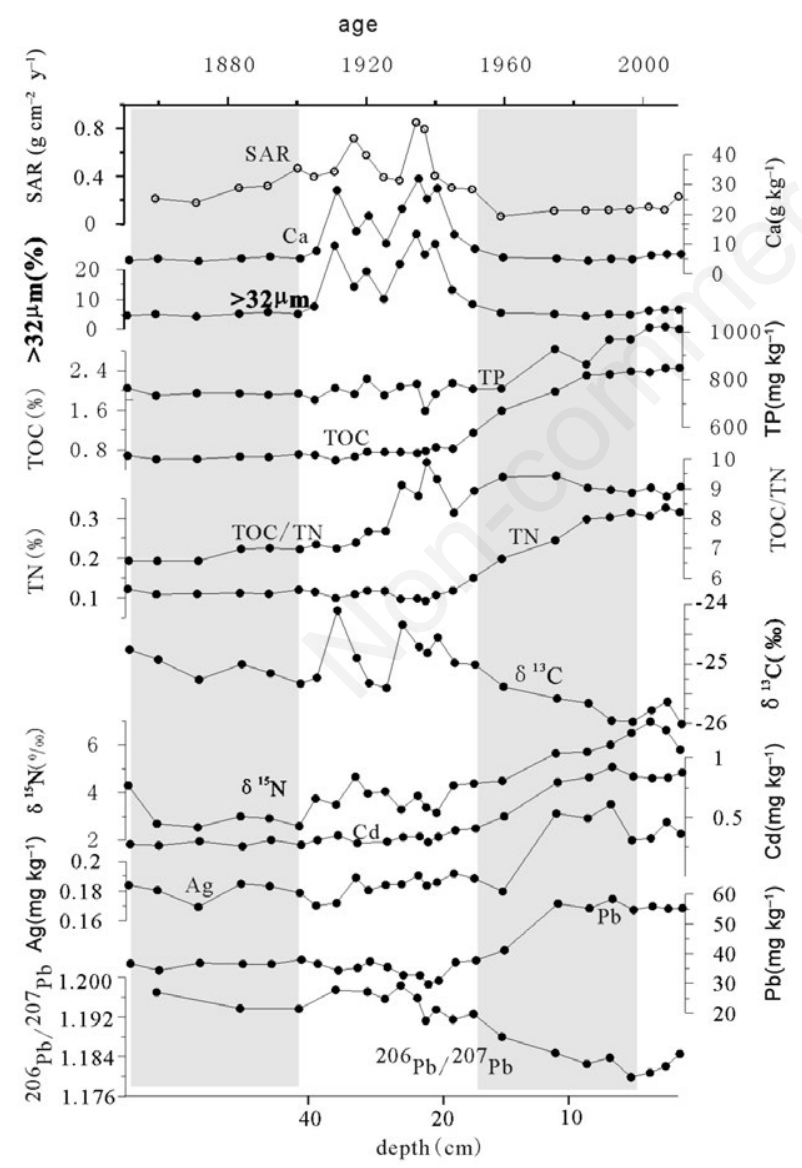

Fig. 3. Summary diagram with time showing sediment accumulation rates (SAR), calcium $(\mathrm{Ca})$, grain size, total organic carbon (TOC), total nitrogen (TN), total phosphorus (TP), TOC/TN, ${ }^{206} \mathrm{~Pb} /{ }^{207} \mathrm{~Pb}, \delta^{13} \mathrm{C}_{\text {org }}$ and $\delta^{15} \mathrm{~N}$ and heavy metals variations for Huanggaihu Lake. can indicate the high content of $\mathrm{Ca}$ during the period 1900-1950 in the Huanggaihu Lake sediments. It is interesting that the Ca profile was consistent with that of the SARs, indicating that the Ca content may be regarded as an indicator of catchment disturbance.

Documented records may give an explanation for why there was severe disturbance in the catchment when the population declined during the 1910s-1940s in the region. In the early period of the Guangxu Emperor (1875), the forest was in pristine condition. During the period 19141920, however, many trees along the railway were felled for the construction of the Yuehan railway. During the period 1938-1945, the Japanese invasion period, all the trees were felled in the district under Japanese control (Chorography Compiling Committee of Puqi County, 1995). The precipitation from 1900-1950 was relatively high for the past 100 years (Gong et al., 2001). The strong rainfall may have caused more terrestrial material to be transported into the lake, resulting in high SARs. The high sedimentation flux in Huanggaihu Lake was likely related to the strong erosion in the catchment, caused by human activities and high precipitation. The human impact was most likely the dominant factor influencing the catchment erosion and SARs during the 1910s-1940s because the SARs were not high when the precipitation was high from 19902000 in the Huanggaihu Lake. The calcareous soil was distributed along or near the railway. During the 1910s1940s, the high soil erosion most likely accelerated the input of carbonate materials from the eastern part to the lake, leading to higher concentrations of $\mathrm{Ca}$ in the sediments during that period.

Human activities influencing sedimentation of Huanggaihu Lake may mainly be the construction of water conservancy facilities around the lake after the construction of water control gate at Tieshanzui. In order to facilitate the agricultural irrigation and flood control, some reservoirs were built in the upper reach of Pan River in 19591967, such as Dongyue, Dahe, Longyuan, Shenglong reservoirs (Chorography Compiling Committee of Lingxiang City, 1995). The reservoirs constructed upstream regulated the water flow and retained the largest particles of soil inorganic and organic material before it could reach the Huanggaihu Lake. Previous studies have found that many lakes along the Yangtze River received both soil from the catchments and materials from the Yangtze River during floods when these lakes connected naturally with the Yangtze River. The construction of water control gate at Tieshanzui may also reduce the sediment loading to Huanggaihu Lake and resulted in low SARs in the lake.

\section{Lake productivity}

The TOC in lake sediments represents a small portion of the organic matter that escapes remineralization during sediment deposition (Meyers, 2003). TOC has been 
widely used to describe the abundance of organic matter and to study the different sources of organic matter, delivery routes, changes in lacustrine palaeoproductivity, preservation and depositional processes (Meyers, 2003; Routh et al. 2004, 2007).

The TOC profile in the Huanggaihu sediments (Fig. 3) indicates important changes in the organic matter supply. The gradual up-core increase in the TOC concentrations after the 1960s suggests a higher input of organic matter. The increase of population and fertilized farming in the lake catchment since the late 1960s could have accelerated nutrient input in the form of raw sewage and agricultural runoff into the lake.

The main drawback of this interpretation of TOC is the post-burial degradation of organic matter, which could significantly affect the TOC content. The degradation of organic matter can reduce TOC concentrations by as much as $20 \%$ in well-oxygenated surface sediments (Routh et $a l$. 2004). Therefore, caution should be taken when interpreting primary productivity using TOC where the sediments were buried in the past few years. However, the TOC profile after the 1960 s seems to reflect the changes in lacustrine palaeoproductivity, despite this possible drawback, because of the corresponding geochemical signatures (e.g., $\delta^{15} \mathrm{~N}$ and $\delta^{13} \mathrm{C}_{\text {org }}$ ) stored in the sediments (discussed later).

\section{Sediment organic matter sources}

In general, phytoplankton has a low TOC/TN atomic ratio, between 4 and 10, whereas vascular land plants have a TOC/TN ratio greater than 20 (Kaushal and Binford, 1999; Meyers and Lallier-Vergès, 1999). Variations in the TOC/TN ratios within the sediment records reflect changes in the contribution of terrestrial or algal organic matter (Kenney et al., 2002). The TOC/TN ratio is widely used as a proxy to distinguish sedimentary organic matter from aquatic or land sources. However, grain size and organic matter degradation may influence TOC/TN, and make the proxy not strong to indicate organic sources in some condition (Wu et al., 2008).

Unlike TOC/TN ratios, the $\delta^{13} \mathrm{C}_{\text {org }}$ value is less sensitive to sediment grain size and organic matter degradation (Schelske and Hodell, 1995). The $\delta^{13} \mathrm{C}_{\text {org }}$ values of organic matter produced by lacustrine algae are significantly different from organic matter from $\mathrm{C} 4$ plants. However, the $\delta^{13} \mathrm{C}_{\text {org }}$ values of organic matter from algae or $\mathrm{C} 3$ vascular plants are often isotopically indistinguishable (Routh et al., 2004). Therefore, the combination of TOC/TN ratios and $\delta^{13} \mathrm{C}_{\text {org }}$ is necessary in reconstructing the source of organic matter in the historical period.

The TOC/TN atomic ratios in the sediments of Huanggaihu Lake were 5.8-9.9, similar to that of lacustrine organic matter, i.e., 4-10, but considerably lower than the $\mathrm{TOC} / \mathrm{TN}$ values for terrestrial $\mathrm{C} 3$ and $\mathrm{C} 4$ plants (Meyers,
1994). In the sediments of the Huanggaihu Lake core, $\delta^{13} \mathrm{C}_{\text {org }}$ values varied between -26.0 and $-23.7 \%$, which is within the range of organic matter from lacustrine algae and land-derived $\mathrm{C} 3$ plants. The integration of TOC/TN ratios and $\delta^{13} \mathrm{C}_{\text {org }}$ data in Huanggaihu Lake suggest a source of primarily aquatically produced organic matter, whereas terrestrially contributed sources are minor.

The recent TOC/TN ratios were higher when compared to the lower part of the Huanggaihu core, which was also shown in studies of lakes Wuliangsu and Nansi (Liu et al., 2010; Wu et al., 2013). However, the range of this ratio over the Huanggaihu core was relatively small. After 1960s slightly lower TOC/TN ratios indicated more contribution of algae into organic matter in Huanggaihu Lake sediment. These topmost sediments with the high TOC/TN ratios did not indicate decreased lacustrine productivity or increased allocthonous materials to the Huanggaihu Lake due to the evidence of increasing productivity, relatively small change in TOC/TN ratios and lower sediment accumulation rates (Figs. 2 and 3). The possible explanation is the increased submergent macrophyte development in the lake because these plants have relatively high TOC/TN ratios (Liu et al., 2010; Wu et al., 2013).

\section{Changes in the accumulation of trace elements}

The ${ }^{206} \mathrm{~Pb} / 207 \mathrm{~Pb}$ ratio is widely used to identify $\mathrm{Pb}$ pollution. The ${ }^{206} \mathrm{~Pb} /{ }^{207} \mathrm{~Pb}$ ratios in Chinese lead ores are lower than the average ${ }^{206} \mathrm{~Pb} /{ }^{207} \mathrm{~Pb}$ ratio of continental crust and marine sediments, which is approximately 1.2 (Renberg et al., 2002; Cheng and Hu, 2010; Xu et al., 2011).

Heavy metal enrichment, including $\mathrm{Pb}, \mathrm{Ag}$ and $\mathrm{Cd}$, occurred after the 1960s (Fig. 3). This enrichment may have been caused by the following factors: the increase of organic bounded heavy metal as organic matter accumulates, the increase of wastewater/atmosphere input, or the formation of the $\mathrm{Fe} / \mathrm{Mn}$ oxide fraction. The increase of anthropogenic heavy metal should be prominent, as evidenced by the ${ }^{206} \mathrm{~Pb} /{ }^{207} \mathrm{~Pb}$ ratio. After the $1960 \mathrm{~s}$, the ${ }^{206} \mathrm{~Pb} /{ }^{207} \mathrm{~Pb}$ ratio decreased rapidly in association with the sharp increase of the $\mathrm{Pb}$ content. If there were no significant anthropogenic input of $\mathrm{Pb}$ to the lake, the sediment $\mathrm{Pb}$ isotope composition would not change, despite the increased sediment $\mathrm{Pb}$ content. The increase of heavy metals after the 1960s was most likely the result of the intensity of human impact in the period, which induced an increase in heavy metal content in the Huanggaihu sediment.

Huanggaihu Lake catchment area is a typical agricultural basin. Phosphate fertilizers contain heavy metals, and the amount is dependent upon the source of the fertilizer, some of which could have significant amounts of metals, particularly $\mathrm{Cd}$ as impurities. Farming activities in the area with phosphate fertilizer inputs to land should be the main source of $\mathrm{Cd}$ in the lake sediment, in case that the industrial source of $\mathrm{Cd}$ around the lake is not clarified. 
There is no evidence showing fertilizer application in Huanggaihu catchment before 1946 (Chorography Compiling Committee of Lingxiang City, 1995). Phosphate fertilizer gradually came into use in 1955 (Chorography Compiling Committee of Lingxiang City, 1995). The continuous use of these fertilizers has led to $\mathrm{Cd}$ accumulation after about 1950 in the watershed, which was achieved in the Huanggaihu Lake system (Fig. 3). Similar findings have also been observed in Chaohu Lake catchment at the Yangtze River basin (Shan and Zhang, 2008). The onset of TP increase lagged behind those of Cd, TOC and TN (Fig. 3), which was likely due to post-depositional mobility. However, after early 1970s the TP profile can track TOC, TN and Cd contents.

\section{$\delta^{13} \mathrm{C}_{\text {org }}$ and $\delta^{15} \mathrm{~N}$}

Many factors can influence the $\delta^{13} \mathrm{C}_{\text {org }}$ of sediment organic matter (Torres et al., 2012; Woodward et al., 2012). The $\delta^{13} \mathrm{C}_{\text {org }}$ signature of autochthonous organic matter is affected by the ${ }^{13} \mathrm{C} /{ }^{12} \mathrm{C}$ ratio of the dissolved inorganic carbon (DIC) in lake water that is used for photosynthesis. The high inputs of carbonate materials from the eastern part to Huanggaihu Lake during the 1910s and the 1940s caused higher concentrations of $\mathrm{Ca}$ in the sediments (Fig. 3). Change in the terrestrial material inputs may increase the concentration of DIC. DIC derived from limestone has a higher $\delta^{13} \mathrm{C}$ value $\left(\delta^{13} \mathrm{C}=1 \%\right.$ ) than that derived from the dissolution of atmospheric $\mathrm{CO}_{2}\left(\delta^{13} \mathrm{C}=-7 \%\right.$ ) (Keeley and Sandquist, 1992). The assimilation of limestone-derived DIC by aquatic plants will result in relatively higher $\delta^{13} \mathrm{C}$ values in sedimentary organic matter (Keeley and Sandquist, 1992). The consistency between the $\delta^{13} \mathrm{C}_{\text {org }}$ and Ca contents during the 1910s and the 1940s in core HGH2011-02 indicate the significant influence of dissolved limestone on the isotope signature of either the DIC or accumulated organic matter (Fig. 3).

The post $1960 \mathrm{~s}$ decline of $\delta^{13} \mathrm{C}_{\text {org }}$ values indicated a contributor of ${ }^{13} \mathrm{C}$-depleted organic carbon to the sediments of Huanggaihu Lake. The change of stable carbon isotope signature of the recent sediment organic matter may indicate changes in the relative abundance of macrophytes $v s$. phytoplankton in Huanggaihu Lake, which was also demonstrated in studies of Lakes Nansihu, Wuliangshuhai and Taihu (Liu et al., 2010; Wu et al., 2007, 2013). The investigation in 2007-2008 by the Nanjing Institute of Geography and Limnology, Chinese Academy of Sciences showed that one of the predominant species of algae was cyanobacterial species. Another contribution to the ${ }^{13} \mathrm{C}$-depleted organic carbon content in the sediments of Huanggaihu may be the expansion of methanotrophic microbial communities. During the fixation of respired carbon by chemoautotrophic organisms, fractionation effects can be greater than those associated with photosynthesis (Kelley et al., 1998; Hollander and Smith, 2001). How- ever, this effect may be minor because the Huanggaihu Lake is very shallow (average water depth of $4.2 \mathrm{~m}$ ). The water column is well mixed and the sediment surface enriched in oxygen. Anoxia at the bottom of the lake may not be common although the productivity increased in recent decades in the Huanggaihu Lake.

The $\delta^{15} \mathrm{~N}$ value of sediment organic matter is generally related to the isotopic composition of dissolved inorganic nitrogen (DIN) in the lake. The elevated sedimentary $\delta^{15} \mathrm{~N}$ values after the 1960s may result from several factors, including high demand for $\mathrm{N}$ when lake productivity enhanced, loading of sewage water and manure to Huanggaihu Lake. As the availability of $\mathrm{NO}_{3}^{-}$is depleted, primary producers discriminate less against the heavier ${ }^{15} \mathrm{NO}_{3}^{-}$, and sediment organic matter incorporates heavier ${ }^{15} \mathrm{~N}$ in Huanggaihu Lake. Algae in the Huanggaihu Lake are limited by $\mathrm{P}$ as revealed by the TN/TP ratios indicating other factors may play a role in producing excursions of up to $5 \%$ in the $\delta^{15} \mathrm{~N}$ signatures. For example, anthropogenic $\mathrm{N}$ inputs with higher $\delta^{15} \mathrm{~N}$ values from sewage effluents may increase the $\delta^{15} \mathrm{~N}$ values. Such inputs have occurred due to the rapid population increase in the Huanggaihu catchment after the end of the 1950s. The decrease of $\delta^{15} \mathrm{~N}$ in the sediments after 2000 can be interpreted as a minor improvement of the lake's water quality because of the decreasing TP. Unfortunately, there was no continuous monitoring of the water in Huanggaihu Lake to provide data that could be used to test our assumption.

\section{CONCLUSIONS}

Environmental changes in Huanggaihu Lake and its catchment since the mid-19 $9^{\text {th }}$ century have left interpretable geochemical imprints in the bottom sediments. The variations in the TOC and TP and the $\delta^{13} \mathrm{C}_{\text {org }}$ and $\delta^{15} \mathrm{~N}$ isotopic compositions indicate that the lake has undergone high primary productivity since the 1960s and that the organic matter is largely composed of aquatic matter. The decrease in geochemical proxies, such as $\delta^{13} \mathrm{C}_{\text {org }}$ and $\delta^{15} \mathrm{~N}$ values, may document improvement in the water quality after 2000 .

\section{ACKNOWLEDGMENTS}

This study represents part of the results of the National Basic Science and Technology Special Project (2012CB956103), the Chinese National Science Foundation (40902048, 41072133), the CAS Strategic Priority Research Program (Grant No. XDA05120602). The authors are very grateful to Mr. Tao Jinkui and Dr. Gui Zhifan for their support and help in the fieldwork. Gratitude should also be expressed to Mr. Xia Weilan and Mr. Zhu Yuxin at the State Key Lab of Lake Science and Environment of the NIGLAS, CAS, for their contribution in the analysis of the sediments. 


\section{REFERENCES}

Appleby PG, 2001. Chronostratigraphic techniques in recent sediments, p. 171-203. In: W.M. Last and J.P. Smol (eds.) Tracking environmental change using lake sediments. Kluwer.

Baskaran M, Naidu A, 1995. ${ }^{210} \mathrm{~Pb}$-derived chronology and the fluxes of ${ }^{210} \mathrm{~Pb}$ and ${ }^{137} \mathrm{Cs}$ isotopes into continental shelf sediments, East Chukchi Sea, Alaskan Arctic. Geochim. Cosmochim. Ac. 59:4435-4448.

Brenner M, Hodell DA, Leyden BW, Curtis JH, Kenney WF, Gu BH, Newman JM, 2006. Mechanisms for organic matter and phosphorus burial in sediments of a shallow, subtropical, macrophyte-dominated lake. J. Paleolimnol. 35:129-148.

Brenner M, Schelske CL, Keenan LW, 2001. Historical rates of sediment and nutrient accumulation in marshes of the Upper St. Johns River Basin, Florida, USA. J. Paleolimnol. 26:241-257.

Brodie CR, Casforda JSL, Lloyda JM, Leng MJ, Heaton THE, Kendrick CP, Zong YQ, 2011. Evidence for bias in C/N, $\delta 13 \mathrm{C}$ and $\delta 15 \mathrm{~N}$ values of bulk organic matter, and on environmental interpretation, of a down-core sedimentary sequence by pre-analysis acid treatment methods. Quaternary Sci. Rev. 30:3076-3087.

Cao JT, 2000. [Sustainable utilization of lake resources in middle and lower reach of Yangtze River basin].[Article in Chinese]. Yangtze River 31:41-43.

Cheng $\mathrm{H}, \mathrm{Hu} \mathrm{Y}, 2010$. Lead $(\mathrm{Pb})$ isotopic fingerprinting and its applications in lead pollution studies in China: a review. Environ. Poll. 158:1134-1146.

Chorography Compiling Committee of Lingxiang City, 1995. [Chorography of Lingxiang County].[Book in Chinese]. Hunan Publishing House.

Chorography Compiling Committee of Puqi County, 1995. [Chorography of Puqi County].[Book in Chinese]. Haitian Publishing House.

Ginn BK, Rühland KM, Young JD, Hawryshyn J, Quinlan R, Dillon PJ, Smol JP, 2012. The perils of using sedimentary phosphorus concentrations for inferring long-term changes in lake nutrient levels: comments on Hiriart-Baer et al. 2011. J. Great Lakes Res. 38:825-829.

Gong D, Zhu J, Wang S. 2001. Flooding 1990s along the Yangtze River, has it concern of global warming? J. Geogr. Sci. 11:43-52.

Hodell DA, Schelske CL, 1998. Production, sedimentation, and isotopic composition of organic matter in Lake Ontario. Limnol. Oceanogr. 43:200-214.

Hollander DJ, Smith MA, 2001. Microbially mediated carbon cycling as a control on the $\delta 13 \mathrm{C}$ of sedimentary carbon in eutrophic Lake Mendota (USA): new models for interpreting isotopic excursions in the sedimentary record. Geochim. Cosmochim. Ac. 65:4321-4337.

Kaushal S, Binford MW, 1999. Relationship between C:N ratios of lake sediments, organic matter sources, and historical deforestation in Lake Pleasant, Massachusetts, USA. J. Paleolimnol. 22:439-442.

Keeley JE, Sandquist D, 1992. Carbon: freshwater plants. Plant Cell Environ. 15:1021-1035.

Kelley CA, Coffin RB, Cifuentes LA, 1998. Stable isotope evidence for alternative bacterial carbon sources in the Gulf of Mexico. Limnol. Oceanogr. 43:1962-1969.

Kenney WF, Waters MN, Schelske CL, Brenner M, 2002. Sed- iment records of phosphorus-driven shifts to phytoplanktondominance in shallow Florida lakes. J. Paleolimnol. 27: 367-377.

Last WM, Smol JP, 2001. Tracking environmental change using lake sediments. 2. Physical and geochemical methods. Springer: 504 pp.

Lehmann MF, Bernasconi SM, Barbieri A, McKenzie JA, 2002. Preservation of organic matter and alteration of its carbon and nitrogen isotope composition during simulated and in situ early sedimentary diagenesis. Geochim. Cosmochim. Ac. 66:3573-3584.

Liu E, Shen J, Zhang E, Wu Y, Yang L, 2010. A geochemical record of recent anthropogenic nutrient loading and enhanced productivity in Lake Nansihu, China. J. Paleolimnol. 44:15-24.

Marcantonio F, Zimmerman, Xu Y, Canuel E, 2002. A Pb isotope record of mid-Atlantic US atmospheric $\mathrm{Pb}$ emissions in Chesapeake Bay sediments. Mar. Chem. 77:123-132.

Meyers PA, 1994. Preservation of source identification of sedimentary organic matter during and after deposition. Chem. Geol. 144:289-302.

Meyers PA, 2003. Applications of organic geochemistry to paleolimnological reconstructions: a summary of examples from the Laurentian Great Lakes. Org. Geochem. 34:261-289.

Meyers PA, Lallier-Vergès E, 1999. Lacustrine sedimentary organic matter records of Late Quaternary paleoclimates. J. Paleolimnol. 21:345-372.

Qin B, Xu P, Wu Q, Luo L, Zhang Y, 2007. Environmental issues of Lake Taihu, China. Hydrobiologia 581:3-14.

Renberg I, Brännvall ML, Bindler R, Emteryd O, 2002. Stable lead isotopes and lake sediments-a useful combination for the study of atmospheric lead pollution history. Sci. Total Environ. 292:45-54.

Routh J, Meyers PA, Gustafsson Ö, Baskaran M, Hallberg E, Schöldström A, 2004. Sedimentary geochemical record of human-induced environmental changes in the Lake Brunnsviken watershed, Sweden. Limnol. Oceanogr. 49: 1560-1569.

Routh J, Meyers PA, Hjorth T, Baskaran M, Hallberg R, 2007. Sedimentary geochemical record of recent environmental changes around Lake Middle Marviken, Sweden. J. Paleolimnol. 37:529-545.

Schelske CL, Hodell DA, 1991. Recent changes in productivity and climate of Lake Ontario detected by isotopic analysis of sediments. Limnol. Oceanogr. 36:961-975.

Schelske CL, Hodell DA, 1995. Using carbon isotopes of bulk sedimentary organic matter to reconstruct the history of nutrient loading and eutrophication in Lake Erie. Limnol. Oceanogr. 40:918-929.

Shan BQ, Zhang H, 2008. Historical records of heavy metal accumulation in sediments and the relationship with agricultural intensification in the Yangtze-Huaihe region, China. Sci. Total Environ 399:113-120.

Torres IC, Inglett PW, Brenner M, Kenney WF, Reddy KR, 2012. Stable isotope $\left(\mathrm{d}^{13} \mathrm{C}\right.$ and $\left.\mathrm{d}^{15} \mathrm{~N}\right)$ values of sediment organic matter in subtropical lakes of different trophic status. J. Paleolimnol. 47:693-706.

Wang SM, Dou HS, 1998. [Chinese lake annals].[Book in Chinese]. Science Press: 265 pp.

Woodward CA, Potito AP, Beilman DW, 2012. Carbon and ni- 
trogen stable isotope ratios in surface sediments from lakes of western Ireland: implications for inferring past lake productivity and nitrogen loading. J. Paleolimnol. 47:167-184.

Wu J, Huang C, Zeng H, Schleser GH, Battarbee R, 2007. Sedimentary evidence for recent eutrophication in the northern basin of Lake Taihu, China: human impacts on a large shallow lake. J. Paleolimnol. 38:13-23.

Wu J, Ma L, Yu H, Zeng H, Liu W, Abuduwaili J, 2013. Sediment geochemical records of environmental change in Lake Wuliangsu, Yellow River Basin, north China. J. Paleolimnol. 50:245-255.

Wu YH, Lucke A, Wang SM, 2008. Assessment of nutrient sources and paleoproductivity during the past century in Longgan Lake, middle reach of the Yangtze River, China. J. Paleolimnol. 39:451-462.
Xu LB, Wu FC, Zheng JA, Xie QL, Li HX, Liao HQ, Zhao XL, Guo F, 2011. Sediment records of $\mathrm{Sb}$ and $\mathrm{Pb}$ stable isotopic ratios in Lake Qinghai. Microchem. J. 97:25-29.

Yang GS, Ma RH, Zhang L, Jiang JH, Yao SC, Zhang M, Zeng $\mathrm{HA}, 2010$. [Lake status, major problems and protection strategy in China].[Article in Chinese]. J. Lake Sci. 22:799-810. (in Chinese)

Yang $\mathrm{H}$, Linge $\mathrm{K}$, Rose $\mathrm{N}, 2007$. The $\mathrm{Pb}$ pollution fingerprint at Lochnagar: The historical record and current status of $\mathrm{Pb}$ isotopes. Environ. Poll. 145:723-729.

Yang X, Anderson N, Don X, Shen J, 2008. Surface sediment diatom assemblages and epilimnetic total phosphorus in large, shallow lakes of the Yangtze floodplain: their relationships and implications for assessing long-term eutrophication. Freshwater Biol. 53:1273-1290. 